\title{
Polyelectrolyte Multilayer Films as Substrates for Photoreceptor Cells
}

\author{
Aysen Tezcaner, ${ }^{\dagger}$ David Hicks, ${ }^{\ddagger}$ Fouzia Boulmedais,,${ }^{\S, l}$ Jose Sahel, ${ }^{\dagger, \ddagger}$ Pierre Schaaf, ${ }^{\perp}$ \\ Jean-Claude Voegel,§,॥ and Philippe Lavalle*,§,॥ \\ Middle East Technical University Department of Engineering Sciences, 06531 Ankara, Turkey, \\ Institut National de la Sante et de la Recherche Medicale, INSERM Unite 592, 184 rue du Faubourg \\ Saint-Antoine, F-75571 Paris Cedex 12, France, Institut National de la Santé et de la Recherche \\ Scientifique, INSERM Unité 595, Faculté de Chirurgie Dentaire, Université Louis Pasteur, 11 rue Humann, \\ F-67085 Strasbourg Cedex, France, and Institut Charles Sadron (CNRS UPR 22), 6 rue Boussingault, \\ F-67083 Strasbourg Cedex, France
}

Received July 20, 2005; Revised Manuscript Received October 7, 2005

\begin{abstract}
Reconstruction of extracellular matrix substrates for delivery of functional photoreceptors is crucial in pathologies such as retinal degeneration and age-related macular degeneration. In this study, we assembled polyelectrolyte films using the layer-by-layer deposition method. The buildup of three different films composed of poly(L-lysine)/ chondroitin sulfate (PLL/CSA), poly(L-lysine)/poly(styrenesulfonate) (PLL/PSS), or poly(L-lysine)/hyaluronic acid (PLL/HA) was followed by means of quartz crystal microbalance measurements, optical waveguide light mode spectroscopy, confocal microscopy, and atomic force microscopy. The exponential growth regime and the diffusion of PLL chains from the bulk through the PLL/CSA, PLL/PSS, and PLL/HA films was examined. Evaluation of photoreceptor cell viability was optimal on one layer of PLL ( $\left.\mathrm{PLL}_{1}\right)$, followed by 10 bilayers of PLL/HA [(PLL/ $\left.\mathrm{HA})_{10}\right]$ and 10 bilayers of PLL/CSA [(PLL/CSA $\left.)_{10}\right]$. The number of bilayers and the type of terminating layer also had a significant influence on the number of photoreceptor cells attached. Functionalized polyelectrolyte multilayer films were obtained by adsorbing basic fibroblastic factor (bFGF) or the insoluble fraction of interphotoreceptor matrix (IPM) on or within polyelectrolyte multilayers. bFGF and IPM adsorption on top of the (PLL/CSA) ${ }_{10} /$ PLL polyelectrolyte films increased the number of photoreceptor cells attached and maintained the differentiation of rod and cone cells.
\end{abstract}

\section{Introduction}

Photoreceptor degeneration leads to an irreversible loss in visual function. Retinitis pigmentosa (RP) is the leading cause of inherited blindness in the developed world and affects approximately 1 in 3000 individuals worldwide. ${ }^{1}$ In many retinal degenerations, photoreceptors and/or retinal pigment epithelium (RPE) degenerate and result in eyesight loss. Cones are seldom directly affected by the identified mutations, and yet in many cases they degenerate secondarily to rods. This constitutes the major cause for loss of central vision and complete blindness.

There are several therapeutic approaches under investigation, namely, viral or nonviral vector mediated gene therapy, ${ }^{2-4}$ pharmacological neuroprotection of photoreceptors through supplementation of vitamin $A,{ }^{5}$ use of trophic factors ${ }^{6-8}$ and calcium blockers, ${ }^{7,9,10}$ and transplantation. ${ }^{11-15}$ Retinal transplantation aims to prevent blindness or to restore eyesight either by rescuing photoreceptor cells or by replacing the damaged photoreceptor cells as dissociated cells ${ }^{11,16,17}$ or intact sheets. ${ }^{12,18}$ Apart from transplantation of cells or tissues from different donor sources (allogeneic, autologous, or xenogeneic), tissue engineering approaches are receiving considerable interest to restore impaired eye functions. Specifically, stem cell based

* To whom correspondence should be addressed. Phone: 333902430 61. Fax: 333902433 79. E-mail: philippe.lavalle@odonto-ulp.u-strasbg.fr. $\dagger$ Middle East Technical University Department of Engineering Sciences.

INSERM U592.

$\S$ INSERM U595.

"Université Louis Pasteur.

${ }^{\perp}$ CNRS, UPR22. therapy is a promising approach in neurodegenerative disorders. ${ }^{15,19}$ Recently, Lavik and co-workers ${ }^{20}$ used blends of poly(L-lactic acid) and poly(lactic acid-co-glycolic acid) foams to deliver retinal progenitor cells to the subretinal space of rat eyes, promoting differentiation of these cells into functional photoreceptors through the laminar organization and structural guidance channels provided.

Tissue engineering requires the formation of a new extracellular matrix (ECM). ECM consists of a very complex mixture of structural and functional macromolecules playing a key role in tissue and organ formation and regeneration and maintenance of the properties and function of tissues and organs. It has long been known that cells differ in their ability to grow and differentiate depending on the chemistry, dynamic composition, and spatial organization of the components and mechanics of their ECM substratum. ${ }^{21-23}$

Many studies have focused on the design of scaffolds or films with properties resembling those of the ECM. However, this remains difficult to achieve. To select appropriate substrates or matrixes, it is necessary to understand the influence of the surface on cell viability, growth, and function. The ability to engineer the interactions of cells with surfaces is of utmost importance, and development of three-dimensional extracellular microenvironments to mimic the regulatory characteristics of natural ECM are still demanding tasks to achieve in medicine. The interphotoreceptor matrix (IPM) receives much attention due to its localization between the photoreceptors and the RPE. A large proportion of the IPM is composed of glycoconjugates, especially chondroitin sulfate-containing proteoglycans ${ }^{24}$ and 
hyaluronic acid. ${ }^{25}$ Their distribution exhibits both apical-basal and photoreceptor cell type specific polarization within the IPM. The precise function of most insoluble IPM constituents is unknown, although the available evidence suggests that some of them may contribute to retinal adhesion or photoreceptor survival. There is also a reservoir of growth factors such as basic fibroblastic growth factor ${ }^{26}$ or pigment epithelium derived factor $^{27}$ which are embedded inside the structure.

Polyelectrolyte film buildup by the alternate adsorption of cationic and anionic layers has emerged as a new and simple approach to modify surfaces in a controlled way. ${ }^{28-32}$ These self-assembly processes of charged polymers involve electrostatic interactions and can be used to build multilayered materials with tunable properties. For conventional polyelectrolyte multilayer systems, the driving force of the buildup process is the alternate overcompensation of the surface charge after each oppositely charged polyelectrolyte deposition. Moreover, ECM components such as collagen and hyaluronic acid can be assembled into polyelectrolyte multilayers using layer-by-layer deposition methods. ${ }^{33}$ Such architectures represent potential strategies for constructing natural ECM analogues for therapeutic applications and basic biological studies.

An exponential increase in thickness and mass with increasing numbers of polyelectrolyte layers deposited on the surface was first described by Elbert et al. for the buildup of poly(L-lysine)/ alginate films. ${ }^{34}$ The construction of poly(L-lysine)/hyaluronic acid (PLL/HA) films described by Picart et al. also takes place over an exponential growth regime. ${ }^{35}$ Several other studies showed that multilayer films exhibiting exponential growth regimes rely on the ability of at least one of the two polyelectrolytes constituting the films (poly(L-lysine) in the case of PLL/ HA films) to diffuse "in" and "out" of the whole structure during each bilayer deposition step. ${ }^{36}$ Chitosan/hyaluronic acid, ${ }^{37}$ poly(L-glutamic acid)/poly(L-lysine), ${ }^{38,39}$ and poly(L-glutamic acid)/ poly(allylamine $)^{40}$ are other examples of films following an exponential growth regime. These exponentially growing films are much less structured and are highly hydrated compared to those growing in a linear fashion. This diffusion mechanism could be related to the biochemical nature of the polyelectrolytes used.

Several groups have used polyelectrolyte multilayers to control cell adhesion and to render the material surface either adhesive or nonadhesive by varying the nature of the polyelectrolytes. ${ }^{31,41-44}$ Proteins can also be easily introduced into such films. ${ }^{32,45-47}$ The maintenance of the biological activity of embedded proteins in the polyelectrolyte multilayers constitutes a remarkable property of these systems, which opens numerous paths to designing biomaterials with specific biological properties (i.e., incorporation of enzymes or hormones). ${ }^{32,48-50}$ For tissue regeneration around an implant, specific adhesion of fibroblasts, chondrocytes, or smooth muscle cells to the biomaterial is generally promoted, whereas the lumen of vascular grafts should be nonadhesive for platelets. ${ }^{34,51,52}$ The chemical composition of polyelectrolyte films can also be responsible for some changes in cellular activity, resulting in uncontrolled inflammatory processes and ultimately in extensive tissue destruction and tissue fibrosis. ${ }^{50}$ This has justified the use of natural polyelectrolytes as polysaccharides or polypeptides to build up multilayers and films. ${ }^{37,53-56}$

The aim of the present study was to mimic the natural matrix of photoreceptor cells by using polyelectrolyte multilayers and to prolong their survival rate in vitro through the addition of growth factors or the insoluble fraction of interphotoreceptor matrix on or within the polyelectrolyte multilayers. Such polyelectrolyte films could act as a reservoir for growth factors. We also evaluated the benefit of different multilayer architectures as biologically compatible substrates for the survival of primary cultured photoreceptor cells. To the best of our knowledge, this study presents fully original work addressing the rational design of polyelectrolyte multilayers with the longterm objective of transplanting photoreceptor cells.

\section{Materials and Methods}

1. Preparation of Polyelectrolyte Multilayer Films. PLL (MW = $\left.5.7 \times 10^{4}\right)$, fluorescein isothiocyanate labeled poly (L-lysine) $\left(\mathrm{PLL}^{\mathrm{FITC}}\right.$; $\left.\mathrm{MW}=5.02 \times 10^{4}\right)$, poly $($ sodium 4-styrenesulfonate) $(\mathrm{PSS} ; \mathrm{MW}=$ $\left.7.0 \times 10^{4}\right)$, and chondroitin sulfate A $\left(\mathrm{CSA} ; \mathrm{MW}=7.5 \times 10^{4}\right)$ were purchased from Sigma (St. Louis, MO). HA $\left(\mathrm{MW}=40 \times 10^{4}\right)$ was received from Biolberica (Barcelona, Spain). All polyelectrolyte solutions were prepared by direct dissolution in $0.15 \mathrm{M} \mathrm{NaCl}$ to a final concentration of $1 \mathrm{mg} / \mathrm{mL}$. The $\mathrm{pH}$ of all polyelectroyte solutions is between 5.8 and 6.0.

The multilayered film was constructed via alternated polycation (PLL) and polyanion (PSS, CSA, or HA) depositions onto $12 \mathrm{~mm}$ glass slides (VWR Scientific, Fontenay-sous-Bois, France) or $\mathrm{SiO}_{2}$ quartz crystal or $\mathrm{Si}_{0.8} \mathrm{~T}_{\mathrm{i} 0.2} \mathrm{O}_{2}$ waveguide surfaces depending on the characterization method. Before polyelectrolyte adsorption, the substrates were cleaned with $0.01 \mathrm{M} \mathrm{SDS}\left(10 \mathrm{~min}\right.$ at $\left.60^{\circ} \mathrm{C}\right)$, rinsed extensively with water, then cleaned with $0.1 \mathrm{M} \mathrm{HCl}\left(10 \mathrm{~min}\right.$ at $\left.60^{\circ} \mathrm{C}\right)$, and again rinsed extensively with water. The substrates which are naturally negatively charged due to partial oxidation in air were dipped first in the polycation solution. Then PSS, HA, or CSA was alternately adsorbed to build $(\mathrm{PLL} / \mathrm{PSS})_{n},(\mathrm{PLL} / \mathrm{HA})_{n}$, or $(\mathrm{PLL} / \mathrm{CSA})_{n}$ multilayered films, where $n$ represents the numbers of adsorbed bilayers. Between each deposition step, the films were rinsed extensively with $0.15 \mathrm{M} \mathrm{NaCl}$ solutions.

The (PLL/PSS $)_{n},(\mathrm{PLL} / \mathrm{HA})_{n}$, or (PLL/CSA $)_{n}$ film buildup processes were followed by quartz crystal microbalance (QCM) measurements and optical waveguide light mode spectroscopy (OWLS). Surface imaging was performed by confocal laser scanning microscopy (CLSM) and atomic force microscopy (AFM).

2. Characterization of Polyelectrolyte Films. a. Quartz Crystal Microbalance Measurements. The construction of (PLL/PSS) ${ }_{n}$, (PLL/ $\mathrm{HA})_{n}$, and (PLL/CSA) ${ }_{n}$ multilayered films was monitored in situ by QCM measurements using the axial flow chamber QAFC 302 (QCMD, D300, Q-Sense, Gõtenborg, Sweden). The QCM technique consists of measuring the resonance frequency changes $(\Delta f)$ induced by polyelectrolyte or protein adsorption onto a quartz crystal, compared to the crystal in contact with $0.15 \mathrm{M} \mathrm{NaCl}$ solution. The quartz crystal is excited at its fundamental frequency $(5 \mathrm{MHz})$, and the measurements are performed at the third overtone (denoted as $v$ ) corresponding to 15 MHz. The crystal used here was coated with a $\sim 50 \mathrm{~nm}$ thick $\mathrm{SiO}_{2}$ film. The measurement methodology has been provided in detail elsewhere. ${ }^{31,33}$ A $0.15 \mathrm{M} \mathrm{NaCl}$ solution was injected into the measurement cell by gravity. After signal stabilization, $500 \mu \mathrm{L}$ of PLL solution was added for $10 \mathrm{~min}$, and the cell was then rinsed for $10 \mathrm{~min}$ with $0.15 \mathrm{M} \mathrm{NaCl}$. Throughout the process, the $\Delta f$ shift was recorded continuously as a function of time. The same procedure was then used for polyanion deposition (PSS, HA, or CSA) by adding $500 \mu \mathrm{L}$ of the corresponding solution. The construction was continued by alternate depositions of PLL and polyanion. A shift in $\Delta f / v$ could be associated in first approximation with a variation of the mass coupled to the crystal according to the Sauerbrey relation: ${ }^{.7}$

$$
m=-C /(-\Delta f / v)
$$

where $C$ is a constant characteristic of the crystal used $(C=17.7$ $\mathrm{ng} \cdot \mathrm{cm}^{-2} \mathrm{~Hz}^{-1}$ in the present experiments).

In our experimental conditions, after the deposition of more than eight layer pairs, the film becomes probably so thick and so hydrated that the signal can no longer be monitored for the four overtones. 
b. Optical Waveguide Lightmode Spectroscopy. The (PLL/PSS) (PLL/HA $)_{n}$, and (PLL/CSA $)_{n}$ film buildup processes were also followed in situ by OWLS. OWLS is sensitive to the penetration depth of an evanescent wave through the film near the waveguide surface (roughly over $150 \mathrm{~nm}$ ) and provides information on optical properties of the films. ${ }^{58,59}$ The thicknesses of the multilayer films were determined using the homogeneous and isotropic monolayer model. ${ }^{60}$ The experimental setup and procedures have been previously described ${ }^{60}$ Polyelectrolytes were adsorbed during $10 \mathrm{~min}$ and rinsed with $0.15 \mathrm{M} \mathrm{NaCl}$ during 10 $\min$.

c. Atomic Force Microscopy. PLL/PSS or PLL/CSA multilayers were deposited on the glass slides as described above, and the surfaces were then observed with an AFM Multimode Nanoscope IV (Veeco, Santa Barbara, CA). Cantilevers, with a spring constant of 0.01 or $0.03 \mathrm{~N} / \mathrm{m}$, ending with a silicon nitride tip were used (model MSCT-AUHW, Veeco). The AFM instrument was operated in constant force contact mode in liquid $(0.15 \mathrm{M} \mathrm{NaCl})$ for each sample. Several scans were imaged over a given surface area to ascertain that there was no sample damage induced by the tip. Height mode images were scanned at a fixed scan rate of $2 \mathrm{~Hz}$ with a resolution of $512 \times 512$ pixels.

d. Confocal Laser Scanning Microscopy. Confocal images were obtained with a Zeiss LSM 510 scanning device mounted on a Zeiss Axiovert 100 inverted microscope. PLL ${ }^{\text {FITC }}$ fluorescence was detected after excitation at $488 \mathrm{~nm}$ with the $1 \%$ power of a $25 \mathrm{~mW}$ argon laser, dichroic mirror, $488 \mathrm{~nm}$, and emission band-pass filter, $505-530 \mathrm{~nm}$ (green channel). All observations were taken using a $40 \times 1.4$ numerical aperture "Plan Apochromat" oil immersion objective and yielded 512 $\times 512$ pixel images. The technique has been described in detail elsewhere. ${ }^{34}$

The (PLL/PSS $)_{n}$ or (PLL/CSA $)_{n}$ multilayered films with a fluorescently labeled PLL FITC layer deposited on top were prepared for CLSM observations with an automatic dipping machine (Dipping Robot DR3, Kirstein and Riegler GmbH, Berlin, Germany) on the glass slides.

3. In Vitro Cell Culture Studies. a. Isolation of Interphotoreceptor Matrix from Pig Eyes. Retinas from pig eyes were dissected free and incubated in phosphate-buffered saline (PBS), $\mathrm{pH} 7.3$, for 7 min under gentle shaking. PBS was replaced with urea buffer (4 M, pH 7.8), and the retina was shaken slowly for $8 \mathrm{~min}$. Insoluble IPM surrounding the retina was removed with the help of forceps under the dissecting microscope. This material was pooled and centrifuged at $3000 \mathrm{rpm}$ for $10 \mathrm{~min}$. PBS was added to the IPM pellet in 10-fold excess (v:v) and passed repeatedly through a mortar until no particulate matter was seen. The extract was then stirred at $4{ }^{\circ} \mathrm{C}$ overnight and centrifuged at 3000 rpm for $15 \mathrm{~min}$ at $4{ }^{\circ} \mathrm{C}$. The solution was dialyzed against PBS (10 $\mathrm{mM}, \mathrm{pH}$ 7.4) overnight, and the contents of the dialysis bag were centrifuged at $35000 \mathrm{rpm}$ at $4{ }^{\circ} \mathrm{C}$ for $2 \mathrm{~h}$, the pellet being collected as the IPM fraction.

b. Adsorption of Basic Fibroblastic Factor and the Insoluble Fraction of Interphotoreceptor Matrix on Polyelectrolyte Multilayer Films. We adsorbed basic fibroblastic factor (bFGF) (100 ng/mL) (R\&D Systems, Abingdon, U.K.) and IPM (diluted 2-fold in $0.15 \mathrm{M} \mathrm{NaCl}$ ) on top of (PLL/CSA) ${ }_{10} / \mathrm{PLL}$ multilayers. After (PLL/CSA) ${ }_{10} / \mathrm{PLL}$ multilayers were built on glass slides, the films were equilibrated with $\mathrm{NaCl}$ solution (0.15 M, pH 7.2) for $15 \mathrm{~min}$. bFGF or IPM in $\mathrm{NaCl}$ was added, and the films were incubated at $37^{\circ} \mathrm{C}$ for $2 \mathrm{~h}$. The films were then washed twice with PBS and sterilized by $30 \mathrm{~min}$ of UV irradiation. Two kinds of films were tested: (i) (PLL/CSA) 9 /PLL films on which bFGF and IPM were adsorbed on the top and (ii) the same films with one more (PLL/CSA) bilayer on top of bFGF or IPM.

c. Enriched Photoreceptor Cell Culture. Primary cultures highly enriched in photoreceptors were prepared from adult domestic pig retinas according to the method of Traverso et al. ${ }^{61}$ The retinal fragments $\left(\sim 1-2 \mathrm{~mm}^{2}\right)$ were incubated with $1 \mathrm{U}$ of activated papain (Worthington Biochemical Corp., Lakewood, NJ) in $0.5 \mathrm{~mL}$ of PBS for $20 \mathrm{~min}$ at 37 ${ }^{\circ} \mathrm{C}$. Digestion was stopped with the addition of Neurobasal medium (Invitrogen, Cergy Pontoise, France) containing 2\% fetal calf serum (Invitrogen) and DNAase I (Sigma). After dissociation of the tissue by gentle shaking, tissue clumps were allowed to settle for $1 \mathrm{~min}$, and the supernatant containing photoreceptor cells was removed. Fresh medium was added to the pellet, and the gentle shaking and supernatant retrieval were repeated once. The pooled supernatants were centrifuged for $5 \mathrm{~min}$ at $800 \mathrm{rpm}$ and finally resuspended in Neurobasal media supplemented with B27 supplement (Invitrogen). Trypan blue vital dye exclusion was used to estimate the number of viable cells. Cells were seeded onto the polyelectrolyte films with an initial seeding density of 400000 cells and cultured at $37^{\circ} \mathrm{C}$ in an incubator under a humidified atmosphere of $5 \% \mathrm{CO}_{2} / 95 \%$ air.

d. Determination of the Viability of Photoreceptor Cells on Polyelectrolyte Films. After $48 \mathrm{~h}$ of incubation, an (dimethylthiazolyl)diphenyltetrazolium bromide (MTT) viability assay was carried out to determine the number of viable cells on the polyelectrolyte films. ${ }^{62}$ Briefly, after different culture incubation times, $25 \mu \mathrm{L}$ of MTT (1.5 $\mathrm{mg} / \mathrm{mL}$, Sigma) was added to the culture medium and the resulting mixture incubated for $20 \mathrm{~h}$ at $37^{\circ} \mathrm{C}$ in the $\mathrm{CO}_{2}$ incubator. The cells were lysed with $1 \mathrm{~mL}$ of $0.08 \mathrm{M} \mathrm{HCl}$ in 2-propanol for $30 \mathrm{~min}$ and subjected to $15 \mathrm{~s}$ of sonication. Optical absorbance was recorded at $570 \mathrm{~nm}$, and background absorbance at $630 \mathrm{~nm}$ was subtracted from each reading.

e. Immunocytochemical Studies. After $48 \mathrm{~h}$ of incubation, the cells were fixed with paraformaldehyde (4\%) for $15 \mathrm{~min}$ at room temperature. They were then permeabilized with Triton X-100 (0.1\% in PBS for 5 min) and saturated with blocking buffer (PBS containing 0.5\% BSA and $0.1 \%$ Tween-20) for $30 \mathrm{~min}$. The cells were incubated with the following primary antibodies: polyclonal anti-human cone arrestin (cones only, gift of Dr. C. Craft, Doheny Eye Institute, University of Southern California, Los Angeles), polyclonal anti-recoverin (rods and cones, gift of Dr. A. Dizhoor, Pennsylvania College of Optometry, Elkins Park, PA), and monoclonal anti-porcine rhodopsin (clone 24H3) (rods only, gift of Dr. G. Hageman, Center for Macular Degeneration, University of Iowa, Iowa City, IA), all diluted in blocking buffer (final concentration $1 \mu \mathrm{g} / \mathrm{mL}$ ) overnight at $4{ }^{\circ} \mathrm{C}$. Following thorough washing, secondary antibody incubation with Alexa (594 or 488) goat anti-rabbit or anti-mouse IgG conjugated antibodies (Molecular Probes, Eugene, OR) was performed at $37^{\circ} \mathrm{C}$ for $1 \mathrm{~h}$. The solution also contained 1 $\mu \mathrm{g} / \mathrm{mL}$ 4'-6-diamidino-2-phenylindole (DAPI; Sigma) to stain the nuclei. Labeled cells were examined under a Nikon Ophtiphot 2 fluorescent microscope and by confocal laser microscopy. The numbers of rods and cones were assessed by counting the respective immunolabeled cells within 10 randomly selected areas and normalized to the total surface area.

f. Scanning Electron Microscopy. The adsorption of the insoluble fraction of IPM was visualized with scanning electron microscopy (SEM). IPM was adsorbed on the polyelectrolyte multilayer as described above, and the slide was washed twice with PBS and 70\% alcohol. The morphology of the photoreceptor cells after seeding was also studied by SEM. The cells were first fixed with paraformaldehyde (4\%) overnight at $4{ }^{\circ} \mathrm{C}$, washed with excessive PBS, air-dried before gold coating, and examined by SEM. All the samples were then dried with a critical point drying apparatus, then mounted on aluminum stubs coated with palladium-gold using a cold sputter-coater, and observed with a Philips XL-20 microscope.

g. Statistical Analysis. All results are expressed as the mean \pm standard deviation (SD). Statistical comparisons were performed using Student's $t$ test, and $p$ values $<0.05$ were considered statistically significant.

\section{Results and Discussion}

The buildup of multilayers of PLL/HA has already been extensively studied. ${ }^{33,34}$ The construction of (PLL/HA) ${ }_{n}$ films takes place over two regimes: the first one occurs from step $n$ $=1$ to step $n=8$ and is characterized by the formation of isolated islands that grow both by addition of new polyelectrolytes to their surface and by mutual coalescence of the islands; 


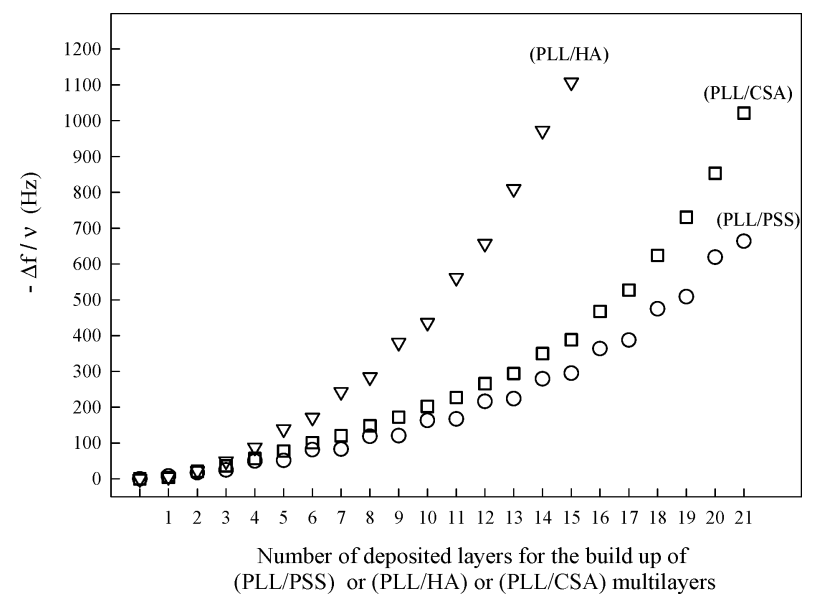

Figure 1. Differences in the QCM frequency shifts $-\Delta f / v$ as a function of the number of deposited layers during the buildup of PLL/CSA ( $\square$ ), PLL/PSS $(O)$, and PLL/HA $(\nabla)$ films (measurements after crystal oscillation at $15 \mathrm{MHz}$ ). All polyelectrolytes were dissolved in $0.15 \mathrm{M}$ $\mathrm{NaCl}$ solutions at $1 \mathrm{mg} / \mathrm{mL}$ and adsorbed during $10 \mathrm{~min}$. Molecular weights are $5.7 \times 10^{4}$ for PLL, $7.0 \times 10^{4}$ for PSS, $7.5 \times 10^{4}$ for CSA, and $40 \times 10^{4}$ for HA.

the second regime sets in once a continuous film is formed after the eighth layer pair deposition and leads to homogeneous layer depositions. However, PLL chains are able to diffuse throughout the film depth after each new PLL addition and out of the film after each new HA addition. The thickness of this new layer is thus proportional to the amount of PLL chains that diffuse out of the film during the buildup step, which leads to an exponential growth regime. HA layers do not diffuse and make the film structure stratified.

In the present study the buildup of two additional polyelectrolyte multilayer films was investigated, PLL/poly(sodium 4-styrenesulfonate) (PLL/PSS) and PLL/chondroitin sulfate A (PLL/CSA), and compared with that of PLL/HA multilayers.

1. Analysis of Film Growth: Physicochemical Characterization of the PLL/CSA and PLL/PSS Films. Figure 1 shows that, with the successive depositions of PLL/CSA, PLL/ PSS, and PLL/HA layer pairs, QCM measurement of $-\Delta f / v$ gradually rose, indicating an increase in both the mass and the thickness of the film. The film buildups of these three systems followed exponential growth curves, as previously described for the PLL/HA system. ${ }^{63}$

To obtain a quantitative estimate of film thicknesses, we performed OWLS analyses. The thicknesses of PLL/CSA and PLL/PSS films increased with successive layer deposition (Figure 2). As suggested previously from QCM data, the thicknesses of both films increased according to an exponential law. The thickness reached after a given number of deposited layers was larger for a (PLL/CSA $)_{7}$ film $(160 \mathrm{~nm})$ than for a $(\mathrm{PLL} / \mathrm{PSS})_{7}$ film $(80 \mathrm{~nm})$. As expected, saturation took place at a thickness of $\sim 150 \mathrm{~nm}$, and the PLL/CSA film became too thick to allow probing of the complete film by the evanescent wave propagating along the guide. ${ }^{33}$ In the case of PLL/HA films, neither the thickness nor the mass could then be determined. ${ }^{33}$ However, AFM or confocal microscopy experiments suggest that the film reaches a thickness of $\sim 1 \mu \mathrm{m}$ after the deposition of 10 bilayers. ${ }^{33,34}$

To check the homogeneity of polymer deposition at the ultrastructural level and to confirm diffusion processes of polyelectrolytes through the film depth, confocal microscopy images of (PLL/PSS $)_{5} / \mathrm{PLL}^{\mathrm{FITC}}$ and (PLL/PSS) ${ }_{10} / \mathrm{PLL}^{\mathrm{FITC}}$ films were acquired (Figure 3). The green fluorescence of both films was distributed homogeneously over the whole surface (Figure

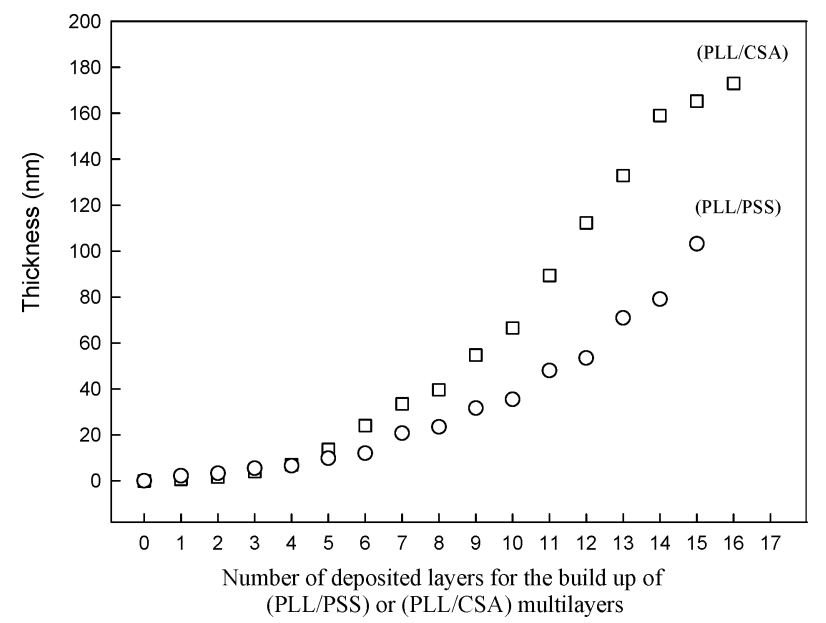

Figure 2. Changes in the thickness of PLL/CSA ( $\square$ ) and PLL/PSS (O) films as a function of each successive layer deposition as measured by the OWLS technique. All polyelectrolytes were dissolved in $0.15 \mathrm{M} \mathrm{NaCl}$ at $1 \mathrm{mg} / \mathrm{mL}$ and adsorbed during $10 \mathrm{~min}$.
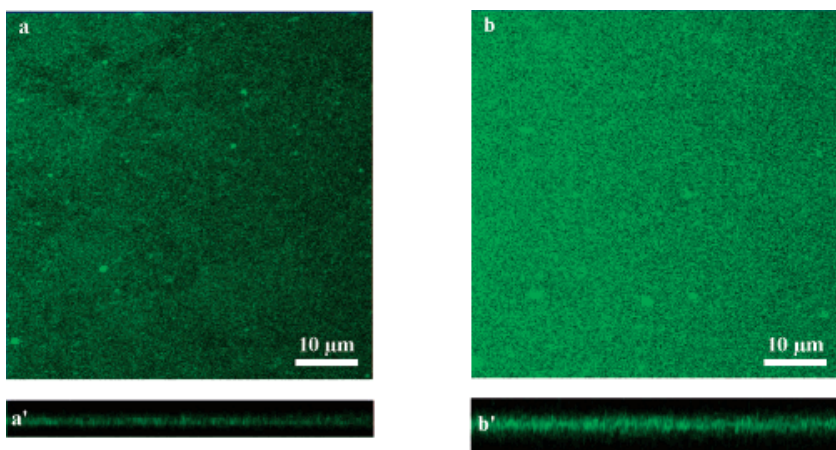

Figure 3. CLSM images of a (PLL/PSS) ${ }_{5} / \mathrm{PLLFITC}$ film (a, $\left.\mathrm{a}^{\prime}\right)$ and a (PLL/PSS) ${ }_{10} / \mathrm{PLL}^{\mathrm{FITC}}$ film $\left(\mathrm{b}, \mathrm{b}^{\prime}\right)$. The $x, y$ image size is $58.5 \times 58.5$ $\mu \mathrm{m}^{2}(\mathrm{a}, \mathrm{b})$, and $x, z$ image sizes are $46.1 \times 5.8 \mu \mathrm{m}^{2}\left(\mathrm{a}^{\prime}\right)$ and $46.1 \times$ $8.4 \mu \mathrm{m}^{2}\left(\mathrm{~b}^{\prime}\right)$.
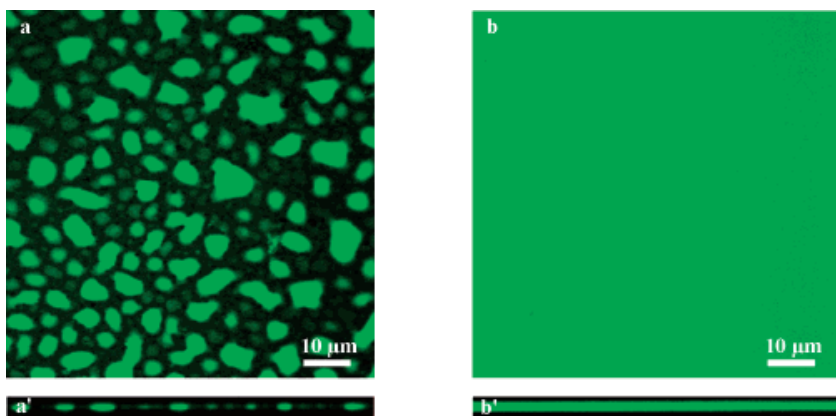

Figure 4. CLSM images of a (PLL/CSA $)_{10} / \mathrm{PLL}^{\mathrm{FITC}}$ film $\left(a, a^{\prime}\right)$ and a (PLL/CSA) ${ }_{20} / \mathrm{PLL}^{\mathrm{FITC}}$ film (b, $\left.\mathrm{b}^{\prime}\right)$. The $x, y$ image size is $76.8 \times 76.8$ $u \mathrm{~m}^{2}(\mathrm{a}, \mathrm{b})$, and $x, z$ image sizes are $76.8 \times 3.8 \mu \mathrm{m}^{2}\left(\mathrm{a}^{\prime}\right)$ and $76.8 \times$ $3.8 \mu \mathrm{m}^{2}\left(\mathrm{~b}^{\prime}\right)$.

$3 \mathrm{a}, \mathrm{b})$. The $x, z$ section also revealed uniform green fluorescence (Figure $3 \mathrm{a}^{\prime}, \mathrm{b}^{\prime}$ ), suggesting that the terminal PLL FITC layer deposited on the top of the film was able to diffuse throughout the film. Such observations have also been described for PLL/ HA multilayer films. ${ }^{34}$ Film thicknesses were difficult to estimate from this technique (resolution in $z$ around $500 \mathrm{~nm}$ ), but clearly the film made of (PLL/PSS $)_{10} / \mathrm{PLL}^{\text {FITC }}$ appeared thicker compared to the (PLL/ PSS) $5 /$ PLL $^{\text {FITC }}$ film.

In the case of (PLL/CSA) ${ }_{10} /$ PLL $^{\text {FITC }}$ (Figure 4a, $\mathrm{a}^{\prime}$ ), a different surface structure was apparent: the film was composed of fluorescent islands $3-8 \mu \mathrm{m}$ in diameter and with a maximum height of $<1 \mu \mathrm{m}$. Most of the surface was covered with 

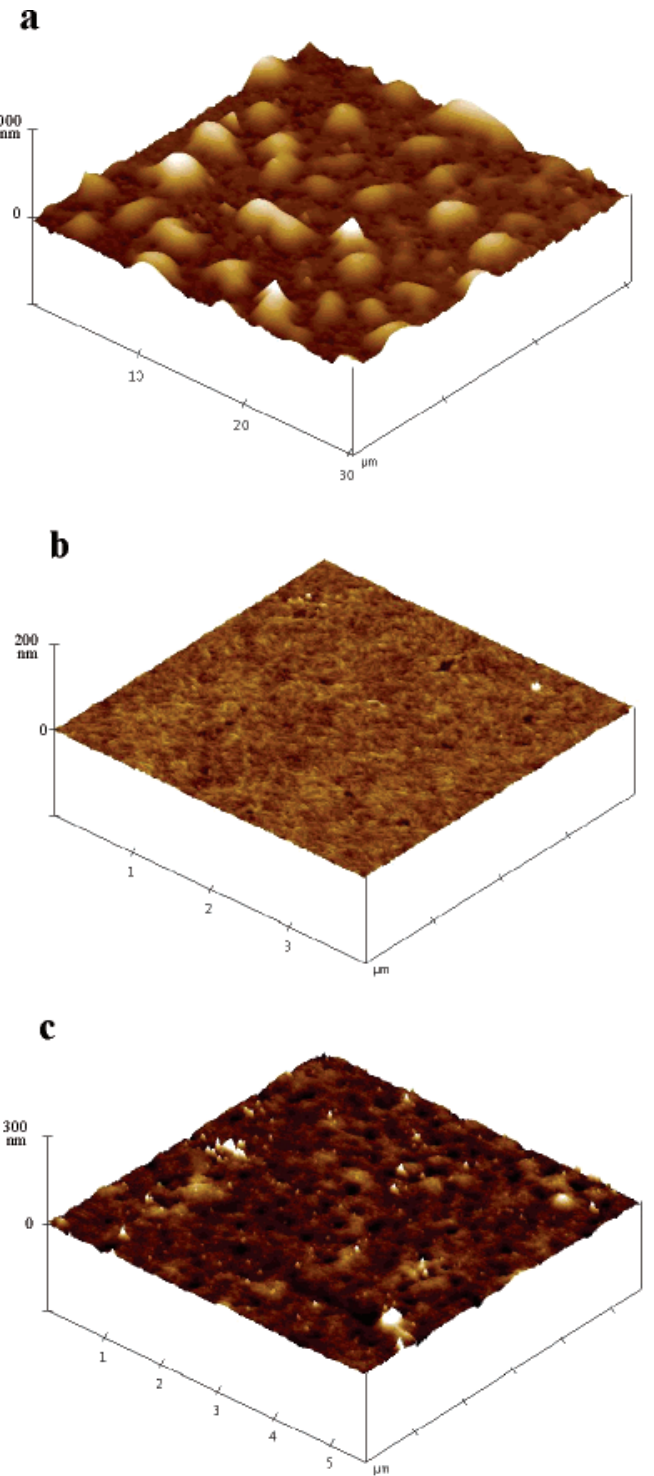

Figure 5. 3D AFM views of the surface topography of (a) (PLL/ CSA) 10 , (b) (PLL/CSA) 20 , and (c) (PLL/PSS) 10 multilayer films.

polyelectrolytes, and the islands were green over the whole thickness. If the number of layers was increased until the formation of (PLL/CSA) ${ }_{20} / \mathrm{PLL}^{\mathrm{FITC}}$, the film became uniform and fluorescence was visualized over a thickness of $\sim 2 \mu \mathrm{m}$ (Figure $4 b, b^{\prime}$ ). This film thus probably resulted from coalescence of islands appearing during deposition of the first 10 bilayers, as was also concluded for PLL/HA. ${ }^{33}$ As the number of layers increased, the islands grew in size, coalesced, and finally covered the full surface. The fluorescence visualized over thicknesses of $>1 \mu \mathrm{m}$ is probably due to diffusion of PLL chains into the film interior after each deposition step.

The surface topographies of (PLL/CSA $)_{10},(\text { PLL/CSA })_{20}$, and $(\mathrm{PLL} / \mathrm{PSS})_{10}$ multilayer films were examined with atomic force microscopy (Figure 5). After deposition of 10 PLL/CSA bilayers, we observed a rough surface texture (mean roughness $R_{\mathrm{a}}=37 \mathrm{~nm}$ for $10 \times 10 \mu \mathrm{m}^{2}$ images) formed of small islands (Figure 5a). After 20 bilayers, the surface was fully covered with polyelectrolyte multilayers (Figure $5 \mathrm{~b}$ ) and the mean roughness became extremely low $\left(R_{\mathrm{a}}=1.0 \mathrm{~nm}\right.$ for $2 \times 2 \mu \mathrm{m}^{2}$ images). This confirmed the confocal microscopy results: during the first stages of deposition of PLL and CSA, the film was composed of islands (at least until 10 bilayers), and then a further increase in the number of layers led to formation of an

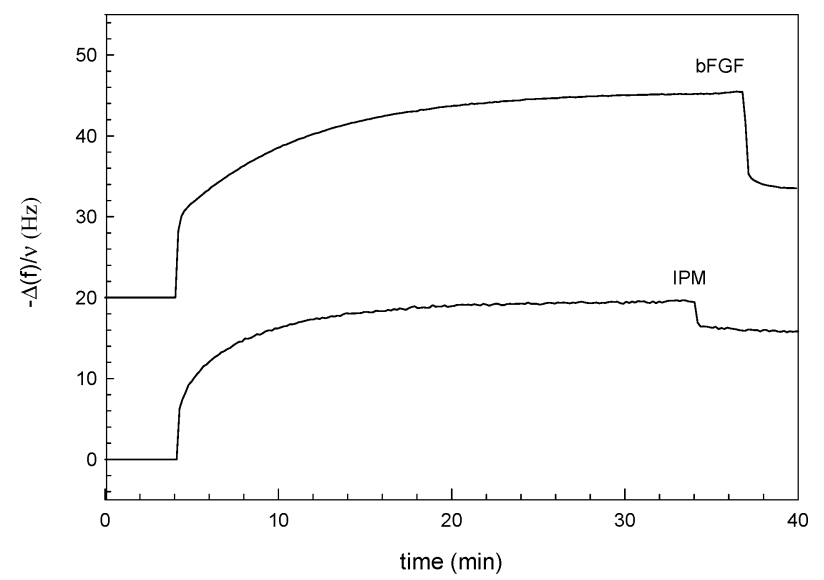

Figure 6. Differences in the QCM frequency shifts $-\Delta f / v$ as a function of time when bFGF $(100 \mathrm{ng} / \mathrm{mL}$ ) and IPM (diluted 2-fold in $0.15 \mathrm{M}$ $\mathrm{NaCl})$ are adsorbed on (PLL/CSA) 6 /PLL multilayer films. For clarity of the presentation, the $-\Delta f / v$ values corresponding to the bFGF curve have been shifted $(+20 \mathrm{~Hz})$.

homogeneous and continuous film. On (PLL/PSS) $)_{10}$ no presence of islands was found, but a homogeneous and granular film with a mean roughness of $3.4 \mathrm{~nm}\left(2 \times 2 \mu \mathrm{m}^{2}\right.$ images $)$ was observed (Figure 5c).

To evaluate the ability of polyelectrolyte multilayers to act as reservoirs for proteins such as growth factors, we monitored the adsorption of $\mathrm{bFGF}$ and IPM on (PLL/CSA) 6 /PLL multilayer films by QCM measurements, through the variations of $-\Delta f / v$. As seen in Figure 6 increments in $-\Delta f / v$ after bFGF and IPM injections were detected, indicating adsorptions of both components onto films. From these data, estimations through the Sauerbrey relation of bFGF and IPM surface densities on the multilayer led respectively to 240 and $280 \mathrm{ng} \cdot \mathrm{cm}^{-2} \cdot 57 \mathrm{We}$ checked also that the addition of further multilayers on top of IPM or bFGF was still possible (data not shown).

2. In Vitro Cell Culture Studies. Developing appropriate coatings for biomaterials is receiving considerable interest by many researchers seeking improvement of the biocompatibility of these materials and preparation of surfaces that can resist or enhance cellular adhesion. Polyelectrolyte multilayer films constitute a novel technique that allows tuning of cellular behaviors. Recently, the viability, adhesion, and adherence of osteoblast-like cells, osteosarcoma cells, and endothelial cells have been investigated by several groups. ${ }^{39,64-66}$

The purity of photoreceptor cells in cultures was determined by immunocytochemical immunostaining to be $\sim 95 \%$. MTT viability assays were performed to determine the number of viable cells on polyelectrolyte films after $48 \mathrm{~h}$ of incubation. As seen in Figure 7, the best substrate for primary photoreceptor cells was a PLL monolayer. However, no statistically significant differences were observed between the PLL monolayer and (PLL/CSA) multilayers ( $n=1, n=10$ without a terminal PLL layer, $n=10$ with a terminal PLL layer) or (PLL/HA) multilayers ( $n=1, n=10$ with a terminal PLL layer). PSS was found to be the least favorable terminating layer for photoreceptor cell viability. For 10 bilayers built by alternating PLL with CSA, HA, or PSS, and ending with PLL, no statistical difference among these polyelectrolyte films was observed for photoreceptor cell viability. However, with CSA as the terminating layer instead of PLL in 10-bilayer films [(PLL/CSA $)_{10}$ versus (PLL/CSA $\left.)_{10} / \mathrm{PLL}\right]$, cell viability and attachment were significantly improved $(p<0.001)$. Figure 7 generally shows that the nature of the terminating layer affected the cells greatly 


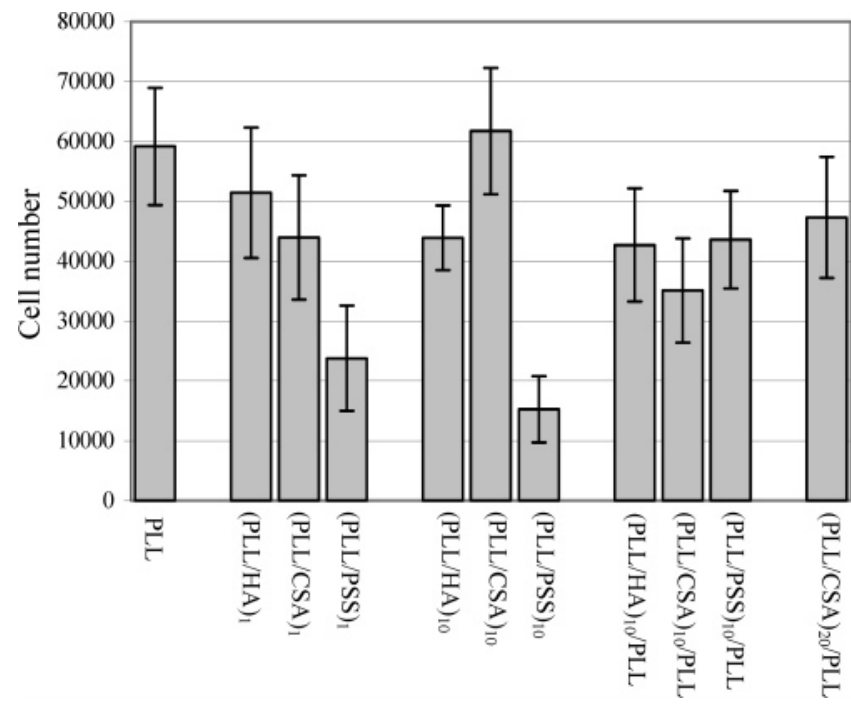

Figure 7. Primary photoreceptor cell survival on different polyelectrolyte films after $48 \mathrm{~h}$ of incubation at $37{ }^{\circ} \mathrm{C}$ in a $\mathrm{CO}_{2}$ incubator in Neurobasal medium supplemented with B27 determined by MTT viability assay. All results are expressed as the mean \pm SD. Statistical comparisons were performed using Student's $t$ test, and $p$ values < 0.05 were considered statistically significant.

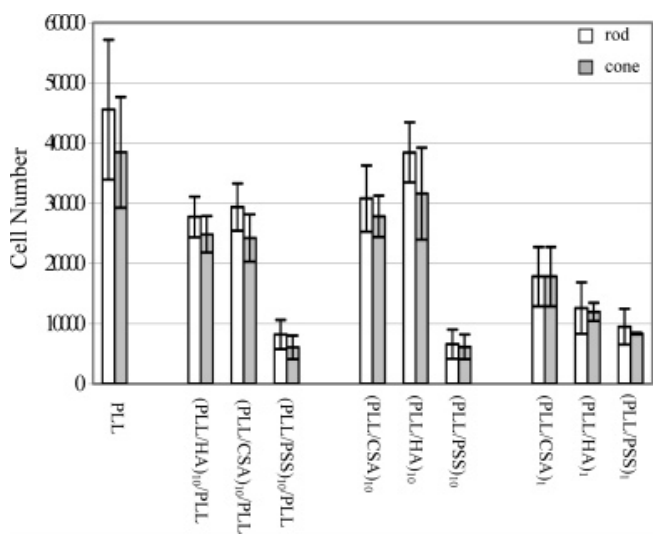

Figure 8. Rod and cone numbers after $48 \mathrm{~h}$ of incubation on different polyelectrolyte films composed of 1 and 10 bilayers of PLL/CSA, PLL/ $\mathrm{HA}$, and PLL/PSS and ending as either PLL or a selected polyanion (CSA, HA, or PSS). All results $(n=4)$ are expressed as the mean \pm SD. Statistical comparisons were performed using Student's $t$ test, and $p$ values $<0.05$ were considered statistically significant.

in terms of viability and attachment, which is in good agreement with the literature. ${ }^{39,40,64}$

From the physicochemical characterization it was concluded that glass slides were not totally covered by (PLL/CSA) 10 multilayers (Figures $4 \mathrm{a}$ and $5 \mathrm{a}$ ). The buildup of 20 bilayers of (PLL/CSA $)_{20}$ resulted in a homogeneous film covering the entire surface (Figures 4b and 5b). However, this change in film structure did not affect the photoreceptor viability, since there was no statistical difference between the total numbers of photoreceptor cells attached on (PLL/CSA) 10 /PLL and (PLL/ CSA) $)_{20} /$ PLL polyelectrolyte multilayers.

Evaluation of the number of each cell type (rods and cones) on glass slides coated with multilayers was determined by counting the cells after specific immunostaining (Figure 8). In vivo, the two different photoreceptor populations are surrounded by different subcompartments of the IPM: rods are bathed in a soluble hyaluronan-rich matrix, cones are surrounded by chondroitin sulfate-rich structures. ${ }^{55}$ Thus, we speculated that terminal surfaces ending with either HA or CSA might exhibit differences in rod or cone attachment. There was however no significant

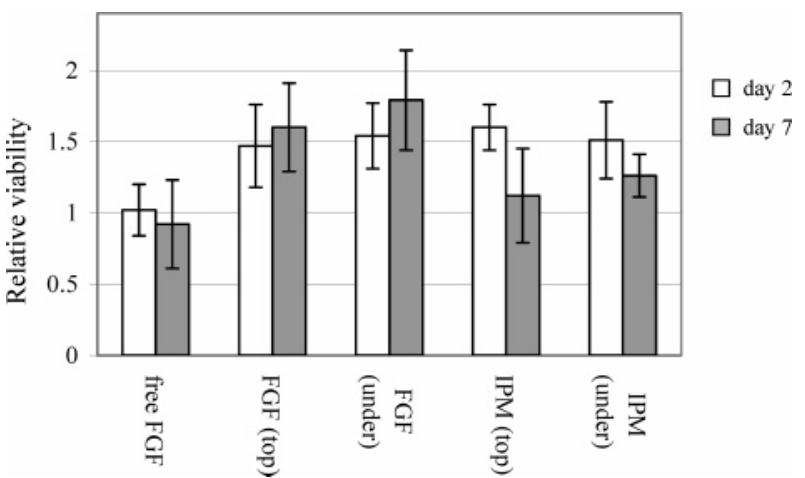

Figure 9. Effect of bFGF and IPM on the survival of photoreceptor cells. The photoreceptor cells were seeded onto (PLL/CSA) ${ }_{10} / \mathrm{PLL}$ multilayers built up on glass slides, and bFGF or IPM was added to the medium ("free bFGF"), adsorbed to the film surface ["FGF (top)" or "IPM (top)", respectively], or adsorbed to the surface which was then coated with one additional bilayer of PLL/CSA ["bFGF (under)" or "IPM (under)", respectively]. The OD values were normalized for each incubation time by comparison to $O D$ values obtained for photoreceptor cells on (PLL/CSA) ${ }_{10} / \mathrm{PLL}$ polyelectrolyte multilayers (controls).

difference between the numbers of rods and cones attached Among the different architectures, the highest number of photoreceptors attached was found for $\mathrm{PLL}_{1},(\mathrm{PLL} / \mathrm{HA})_{10}$, and (PLL/CSA $)_{10}$. The number of pairs of layers and the type of terminating layer had significant effects on the total number of photoreceptor cells attached. The number of photoreceptor cells attached to (PLL/PSS) $)_{10} / \mathrm{PLL}$ polyelectrolyte films was much less than that for (PLL/CSA) $)_{10} / \mathrm{PLL}$ and (PLL/HA) $10 / \mathrm{PLL}$ multilayers. Viability assays and immunostaining data were basically similar (compare Figures 7 and 8), since PSS was the worst for photoreceptor numbers in both cases and PLL was the best. There were slight differences between the two approaches, which may be due to cell damage caused by handling.

The development of new strategies providing precise control of the microenvironment is of prime importance for regeneration and tissue engineering since ECM can affect cell behavior in at least two ways. First, cell-ECM interaction may regulate cell functions through receptor-mediated signaling. Second, ECM can control the mobilization and presentation of growth and differentiation factors, thus modulating cell proliferation and controlling the cell phenotype. ${ }^{23,67,68}$ The effects of different neurotrophic factors secreted from different retinal cells (glial cell-, RPE cell-, and neuronal-derived) on cell survival and differentiation are being actively studied. ${ }^{61,62,69-72}$ Buildup of multilayered polyelectrolyte films could constitute a useful tool for the three-dimensional control of the spatial or surface arrangement and composition of ECM analogues. The maintenance of biological activity of embedded proteins in the polyelectrolyte multilayers could allow biomaterials with tailored biological properties to be designed. We therefore added bFGF and IPM on top, or one bilayer beneath the film surface, to mimic ECM.

The relative viability of photoreceptor cells at days 2 and 7 was determined by MTT tests and OD measurements obtained for (PLL/CSA) ${ }_{10} /$ PLL polyelectrolyte multilayers (Figure 9). In accordance with the literature ${ }^{61}$ bFGF supplementation in the medium did not increase the survival rate relative to that of the controls after 7 days in vitro. The survival-promoting effect of free bFGF could be observed when the cells were incubated for longer periods (data not shown). However, adsorption of bFGF either on top or beneath a terminal bilayer resulted in 

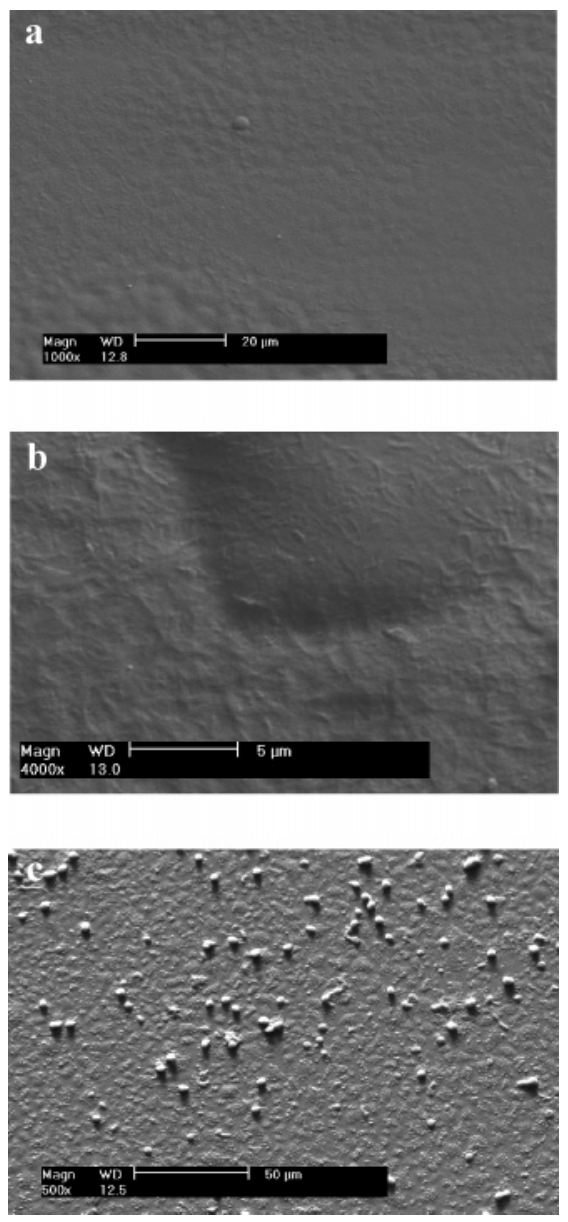

Figure 10. SEM micrographs of (PLL/CSA) $10 / P L L$ bilayers (a) before IPM adsorption and photoreceptor cell seeding, (b) after IPM adsorption, and (c) $48 \mathrm{~h}$ after photoreceptor cell seeding.

statistically significant increases in survival compared to that of the controls and also to that of free bFGF at days 2 and 7 ( $p$ $<0.05)$. The reasons for differences between photoreceptor cells supplemented with free and adsorbed bFGF could be multiple. For example, the local concentration of bFGF at the film surface could be larger than in the bulk solution. Moreover, the direct binding of growth factors to PLL might also affect biological activity, since protein folding may be different when bFGF is attached to a solid substrate, optimizing its presentation to cell membrane receptors. It should be noted that bFGF is usually attached to a matrix or carrier molecules, such as basement membrane, proteoglycan, or soluble receptor. ${ }^{55}$ Matrix-dependent enhancement of growth factor effects has been previously demonstrated by Ma et al., ${ }^{73}$ who observed that FGFs incorporated in a collagen layer immobilized on PLLA surfaces further stimulated chondrocyte cell growth.

Stability of the differentiated cell state is crucial for functionality of the construction to be transplanted. The effect of supplementation with free bFGF, and adsorbed bFGF or the insoluble fraction of IPM on top and within the polyelectrolyte substrate, on the expression of photoreceptor-specific markers was also studied (Figures 10 and 11). The glass slides coated with polyelectrolyte films only were visualized as smooth surfaces by SEM (Figure 10a), whereas the presence of the insoluble fraction of IPM was seen in the form of fibrils (Figure 10b). ${ }^{56,74}$ Photoreceptor cells on IPM-adsorbed polyelectrolyte films are shown in Figure 10c.

When cell numbers were scored after 2 days in vitro, there were greater numbers of immunolabeled cones in the presence
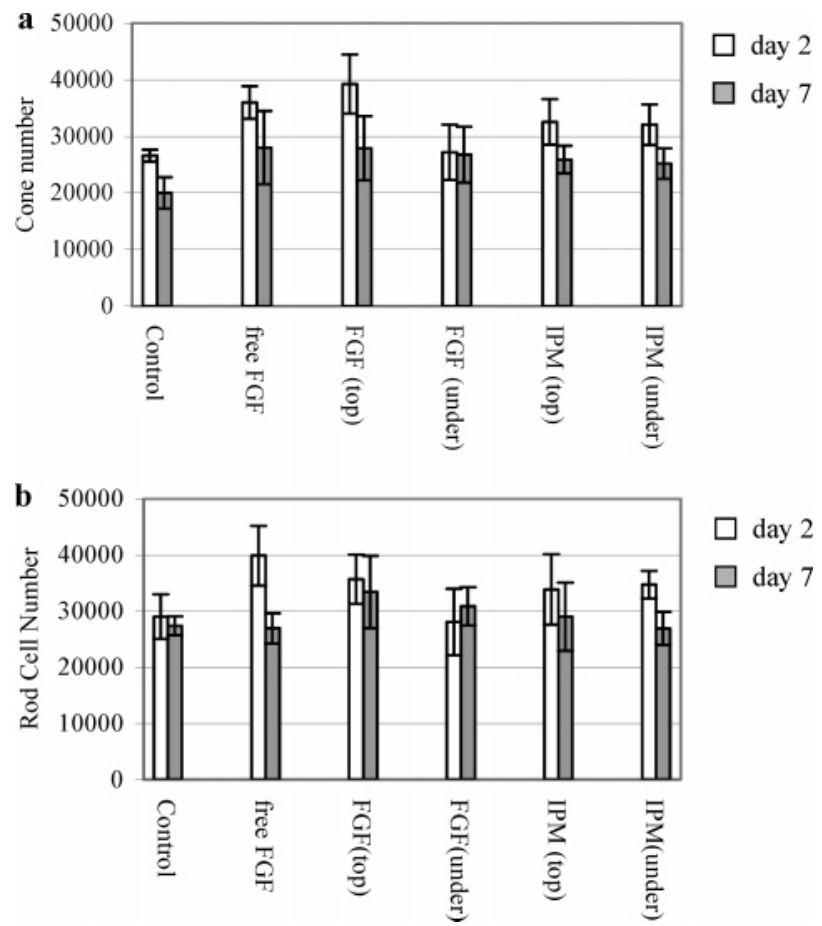

Figure 11. Effects of bFGF and IPM on the number of (a) cones and (b) rods at days 2 and 7 . The photoreceptor cells were seeded onto (PLL/CSA) ${ }_{10} /$ PLL multilayers built up on glass slides, and bFGF or IPM was added to the medium ("free bFGF"), adsorbed to the film surface ["FGF (top)" or "IPM (top)", respectively], or adsorbed to the surface which was then coated with one additional bilayer of PLL/ CSA ["bFGF (under)" or "IPM (under)", respectively].

of free bFGF and IPM adsorbed on top $(p<0.05)$ than on (PLL/ CSA) ${ }_{10} /$ PLL multilayers alone (Figure $11 \mathrm{a}$, white bars). By contrast, except for free bFGF supplementation to the culture medium, there were no statistical differences in rod cell numbers at this same time point (Figure 11b, white bars). When calculated as total photoreceptor numbers (rods plus cones), significant increases compared to that of the control substrate were seen for all treatments except "bFGF under". These increases were not always seen when survival was measured by viability assay (Figure 9), which may in part be due to immunolabeling of some dying cells in addition to viable ones. Although no statistical differences for cone or rod cell numbers on modified film surfaces were observed on day 7 when evaluated separately (Figure 11), the total photoreceptor cell number (rods plus cones) seeded on bFGF adsorbed on top was found to be statistically higher than that of the controls ( $p<0.05$ ) (not shown). In general, the data indicate that bFGF has more effect on cone survival than that on rods under the present experimental conditions, which may be due to selective expression of specific FGF receptors on cones. ${ }^{75}$

Preliminary detachment experiments of polyelectrolyte multilayer films from the glass slides were also undertaken. After the buildup of 60 bilayers of PLL/CSA, the film was crosslinked with carbodiimide/hydroxysuccinimide (EDC/NHS) for $12 \mathrm{~h}$ as previously described. ${ }^{76}$ Detachment of the polyelectrolyte multilayer film was realized by immersion in an alkaline solution $(\mathrm{NaOH}, 0.1 \mathrm{M})$ for $30 \mathrm{~min}$. Polyelectrolyte films could often be detached from the glass slides without breaking, but complete detachment was not always successful. Figure 12a constitutes an example of a piece of the detached multilayer as visualized by SEM. Following detachment, the films were placed in 24 culture wells and primary photoreceptor cells were seeded on top at an initial density of $1 \times 10^{6}$ cells/film. As seen in Figure 

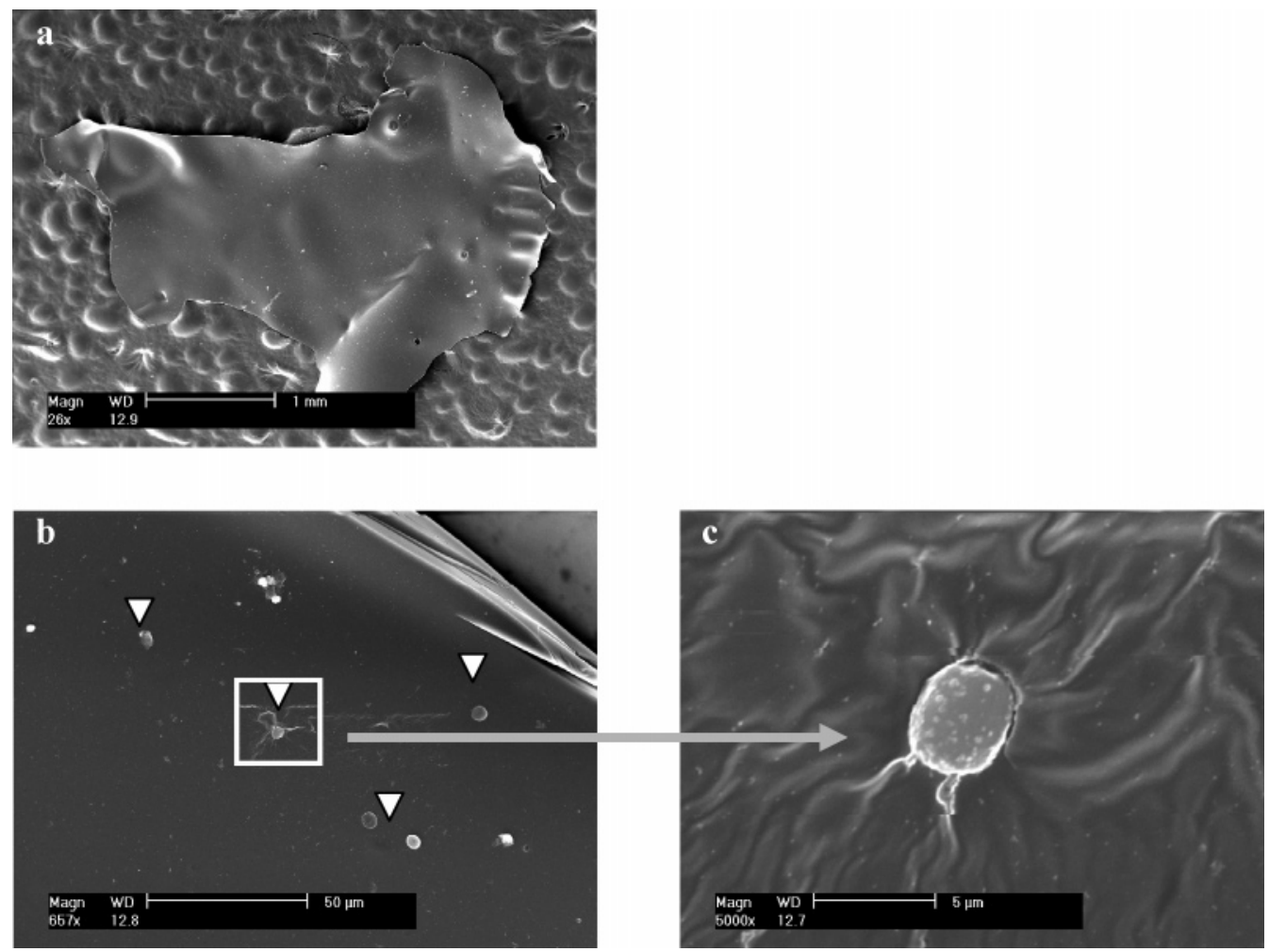

Figure 12. SEM micrographs of (a) a piece of detached polyelectrolyte film deposited on a granular glue surface, (b) photoreceptor cells seeded onto the detached film at an initial seeding density of $1 \times 10^{6}$ cells/film, and (c) an enlargement of a photoreceptor cell. Arrowheads represent the photoreceptor cells.

$12 \mathrm{~b}, \mathrm{c}$, cell attachment on the detached film was very low. A more efficient method will be tested in the future using strategies of functionalized films to maximize photoreceptor cell adhesion. However, this approach requires the availability of mechanically stable membranes to permit their recovery at the end of incubation. Preliminary tests performed with fragile films showed promising results for future studies on temporary selfstanding templates for subretinal photoreceptor delivery.

\section{Conclusion}

In this study, we assembled polyelectrolyte films using the layer-by-layer deposition method. PLL was used as a polycation, and CSA, PSS, or HA as a polyanion. These three different films composed of PLL/CSA, PLL/PSS, or PLL/HA exhibited an exponential growth regime, and the polyanion, polycation, or both polyelectrolytes were able to diffuse throughout the entire multilayer depth. From the different systems evaluated, the highest numbers of photoreceptors attached were obtained for $\mathrm{PLL}_{1}$ and (PLL/HA) $)_{10}$, followed by (PLL/CSA) 10 . PSS was found to be the least favorable terminating layer for photoreceptor cell viability. Functionalized polyelectrolyte multilayer films were obtained by adsorbing bFGF or the insoluble fraction of IPM on or within the PLL/CSA polyelectrolyte multilayers. bFGF and IPM adsorption on top of the (PLL/CSA) $)_{10} / \mathrm{PLL}$ polyelectrolyte films increased the number of photoreceptor cells attached, and in particular bFGF adsorbed on the top led to a statistically significant increase in photoreceptor cell survival at day 7. This convenient and effective layer-by-layer method can be used to prepare bioactive membranes with extracellular matrixlike composition, for the purposes of functionalized tissue engineering. Such very thin films can be detached and exhibit the potential to deliver photoreceptor cells within the subretinal space and ensure a controlled laminar organization and maintenance of differentiation.
Acknowledgment. A.T. thanks the Scientific and Technical Research Council of Turkey for financial support through the "NATOB1 grant". We thank Jérôme Mutterer (Institut de Biologie Moléculaire des Plantes, CNRS/ULP, Strasbourg, France) for his help with the CLSM. The CLSM platform used in this study was cofinanced by the Région Alsace, the Université Louis Pasteur, and the Association pour la Recherche sur le Cancer. We also thank Nadia Messaddeq (Institut de Génétique et Biologie Moléculaire et Cellulaire, CNRS/ULP/ INSERM, Illkirch, France) for her technical assistance with SEM.

\section{References and Notes}

(1) Delyfer, M. N.; Leveillard, T.; Mohand-Said, S.; Hicks, D.; Picaud, S.; Sahel, Biol. Cell 2004, 96, 261-269.

(2) Bennett, J.; Zeng, Y.; Bajwa, R.; Klatt, L.; Li, Y.; Maguire, A. M. Gene Ther. 1998, 5, 1156-1164.

(3) D'Cruz, P. M.; Yasumura, D.; Weir, J.; Matthes, M. T.; Abderrahim, H.; LaVail, M. M.; Vollrath, D. Hum. Mol. Genet. 2000, 9, 645651.

(4) McGee Sanftner, L. H.; Abel, H.; Hauswirth, W. W.; Flannery, J. G. Mol. Ther. 2001, 4, 622-629.

(5) Li, T.; Sandberg, M. A.; Pawlyk, B. S.; Rosner, B.; Hayes, K. C.; Dryja, T. P.; Berson, E. L. Proc. Natl. Acad. Sci. U.S.A. 1998, 95, 11933-11938.

(6) LaVail, M. M.; Yasumura, D.; Matthes, M. T.; Lau-Villacorta, C.; Unoki, K.; Sung, C. H.; Steinberg, R. H. Invest. Ophthalmol. Visual Sci. 1998, 39, 592-602.

(7) Frasson, M.; Picaud, S.; Leveillard, T.; Simonutti, M.; Mohand-Said, S.; Dreyfus, H.; Hicks, D.; Sahel, J. Invest. Ophthalmol. Visual Sci. 1999, 40, 2724-2734.

(8) Bok, D.; Yasumura, D.; Matthes, M. T.; Ruiz, A.; Duncan, J. L.; Chappelow, A. V.; Zolutukhin, S.; Hauswirth, W.; Lavail, M. M. Exp. Eye Res. 2002, 74, 719-735.

(9) Kommonen, B.; Kylma, T.; Cohen, R. J.; Penn, J. S.; Paulin, L.; Hurwitz, M.; Hurwitz, R. L. Ophthalmic Res. 1996, 28, 19-28.

(10) Lee, K. S.; Tsien, R. W. Nature 1983, 302, 790-794.

(11) Turner, J. E.; Blair, J. R. Brain Res. 1986, 391, 91-104. 
(12) Mohand-Said, S.; Hicks, D.; Simonutti, M.; Tran-Minh, D.; DeudonCombe, A.; Dreyfus, H.; Silverman, M. S.; Ogilvie, J. M.; Tenkova, T.; Sahel, J. Ophthalmic Res. 1997, 29, 290-297.

(13) Ahmad, I.; Dooley, C. M.; Thoreson, W. B.; Rogers, J. A.; Afiat, S. Brain Res. 1999, 831, 1-10.

(14) Chacko, D. M.; Rogers, J. A.; Turner, J. E.; Ahmad, I. Biochem. Biophys. Res. Commun. 2000, 268, 842-846.

(15) Kicic, A.; Shen, W. Y.; Wilson, A. S.; Constable, I. J.; Robertson, T.; Rakoczy, P. E. J. Neurosci. 2003, 23, 7742-7749.

(16) Aramant, R.; Seiler, M.; Turner, J. E. Invest. Ophthalmol Visual Sci. 1988, 29, 498-503.

(17) Seiler, M. J.; Aramant, R. B. Invest. Ophthalmol Visual Sci. 1998 , 39, 2121-2131.

(18) Silverman, M. S.; Hughes, S. E. Invest. Ophthalmol Visual Sci. 1989 30, 1684-1690.

(19) Tomita, M.; Adachi, Y.; Yamada, H.; Takahashi, K.; Kiuchi, K.; Oyaizu, H.; Ikebukuro, K.; Kaneda, H.; Matsumura, M.; Ikehara, S. Stem Cells 2002, 20, 279-283.

(20) Lavik, E. B.; Klassen, H.; Warfvinge, K.; Langer, R.; Young, M. J. Biomaterials 2005, 26, 3187-3196.

(21) Ingber, D. E.; Bell, E., Ed.; In Extracellular matrix. Cellular mechanics and tissue engineering. Birkhauser: Boston, Basel, Berlin, 1993; pp 3-19.

(22) Rosso, F.; Giordano, A.; Barbarisi, M.; Barbarisi, A. J. Cell Physiol. 2004, 199, 174-180.

(23) Lutolf, M. P.; Hubbell, J. A. Nat. Biotechnol. 2005, 23, 47-55.

(24) Hageman, G. S.; Johnson, L. V. Prog. Retinal Res. 1991, 10, $208-$ 249.

(25) Hollyfield, J. G. Invest. Ophthalmol. Visual Sci. 1999, 40, 27672769

(26) Hageman, G. S.; Kirchoff-Rempe, M. A.; Lewis, G. P.; Fisher, S K.; Anderson, D. H. Proc. Natl. Acad. Sci. U.S.A. 1991, 88, 67066710 .

(27) Becerra, S. P.; Fariss, R. N.; Wu, Y. Q.; Montuenga, L. M.; Wong, P.; Pfeffer, B. A. Exp. Eye Res. 2004, 78, 223-234.

(28) Decher, G.; Hong, J. D.; Schmitt, J. Thin Solid Films 1992, 210, $831-835$.

(29) Decher, G. Science 1997, 277, 1232-1237.

(30) Ladam, G.; Schaad, P.; Voegel, J.-C.; Schaaf, P.; Decher, G.; Cuisinier, F. Langmuir 2000, 16, 1249-1255.

(31) Zhu, Y. B.; Gao, C. Y.; He, T.; Liu, X. Y.; Shen, J. C. Biomacromolecules 2003, 4, 446-452.

(32) Jessel, N.; Atalar, F.; Lavalle, P.; Mutterer, J.; Decher, G.; Schaaf, P.; Voegel, J.-C.; Ogier, J. Adv. Mater. 2003, 15, 692-695.

(33) Zhang, J.; Senger, B.; Vautier, D.; Picart, C.; Schaaf, P.; Voegel, J.-C.; Lavalle, P. Biomaterials 2005, 26, 3353-3361.

(34) Elbert, D. L.; Herbert, C. B.; Hubbell, J. A. Langmuir 1999, 15, 5355-5362.

(35) Picart, C.; Lavalle, P.; Hubert, P.; Cuisinier, F. J. G.; Decher, G.; Schaaf, P.; Voegel, J.-C. Langmuir 2001, 17, 7414-7424.

(36) Picart, C.; Mutterer, J.; Richert, L.; Luo, Y.; Prestwich, G. D.; Schaaf, P.; Voegel, J.-C.; Lavalle, P. Proc. Natl. Acad. Sci. U.S.A. 2002, 99, $12531-12535$

(37) Richert, L.; Lavalle, P.; Payan, E.; Zheng, X. S.; Prestwich, G. D.; Stoltz, J. F.; Schaaf, P.; Voegel, J.-C.; Picart, C. Langmuir 2004, $20,448-458$

(38) Lavalle, P.; Vivet, V.; Jessel, N.; Decher, G.; Mesini, P. J.; Voegel, J.-C.; Schaaf, P. Macromolecules 2004, 37, 1159-1162.

(39) Boulmedais, F.; Ball, V.; Schwinte, P.; Frisch, B.; Schaaf, P.; Voegel, J.-C. Langmuir 2003, 19, 440-445.

(40) Boulmedais, F.; Bozonnet, M.; Schwinté, P.; Voegel, J.-C.; Schaaf, P. Langmuir 2003, 19, 9873-9882.

(41) Boura, C.; Menu, P.; Payan, E.; Picart, C.; Voegel, J.-C.; Muller, S.; Stoltz, J. F. Biomaterials 2003, 24, 3521-3530.

(42) Mendelsohn, J. D.; Yang, S. Y.; Hiller, J.; Hochbaum, A. I.; Rubner, M. F. Biomacromolecules 2003, 4, 96-106.

(43) Richert, L.; Boulmedais, F.; Lavalle, P.; Mutterer, J.; Ferreux, E.; Decher, G.; Schaaf, P.; Voegel, J.-C.; Picart, C. Biomacromolecules 2004, 5, 284-294.
(44) Zhu, H.; Ji, J.; Shen, J. Biomaterials 2004, 25, 109-117.

(45) Salloum, D. S.; Schlenoff, J. B. Biomacromolecules 2004, 5, 10891096.

(46) Caruso, F.; Niikura, K.; Furlong, D. N.; Okahata, Y. Langmuir 1997, 13, 3427-3433.

(47) Lvov, Y.; Ariga, K.; Ichinose, I.; Kunitake, T. J. Am. Chem. Soc 1995, 117, 6117-6123.

(48) Chluba, J.; Voegel, J.-C.; Decher, G.; Erbacher, P.; Schaaf, P.; Ogier, J. Biomacromolecules 2001, 2, 800-805.

(49) Derbal, L.; Lesot, H.; Voegel, J.-C.; Ball, V. Biomacromolecules 2003, 4, 1255-1263

(50) Jessel, N.; Lavalle, P.; Meyer, F.; Audouin, F.; Frisch, B.; Schaaf, P.; Ogier, J.; Decher, G.; Voegel, J.-C. Adv. Mater. 2004, 16, 15071511

(51) Seal, B. L.; Otero, T. C.; Panitch, A. Mater. Sci. Eng., R 2001, 34, $147-230$

(52) Thierry, B.; Winnik, F. M.; Merhi, Y.; Tabrizian, M. J. Am. Chem. Soc. 2003, 125, 7494-7495.

(53) Burke, S. E.; Barrett, C. J. Biomacromolecules 2003, 4, 1773-1783.

(54) Thierry, B.; Winnik, F. M.; Merhi, Y.; Silver, J.; Tabrizian, M. Biomacromolecules 2003, 4, 1564-1571.

(55) Khademhosseini, A.; Suh, K. Y.; Yang, J. M.; Eng, G.; Yeh, J.; Levenberg, S.; Langer, R. Biomaterials 2004, 25, 3583-3592.

(56) Barbucci, R.; Magnani, A.; Lamponi, S.; Pasqui, D.; Bryan, S. Biomaterials 2003, 24, 915-926.

(57) Sauerbrey, G. Z. Phys. 1959, 155, 206-222.

(58) Tiefenthaler, K.; Lukosz, W. J. Opt. Soc. Am. B 1989, 6, 209-220.

(59) Voros, J.; Ramsden, J. J.; Csucs, G.; Szendro, I.; De Paul, S. M.; Textor, M.; Spencer, N. D. Biomaterials 2002, 23, 3699-3710.

(60) Picart, C.; Ladam, G.; Senger, B.; Voegel, J.-C.; Schaaf, P.; Cuisinier, F. J. G.; Gergely, C. J. Chem. Phys. 2001, 115, 1086-1094.

(61) Traverso, V.; Kinkl, N.; Grimm, L.; Sahel, J.; Hicks, D. Invest. Ophthalmol. Visual Sci. 2003, 44, 4550-4558.

(62) Fintz, A. C.; Audo, I.; Hicks, D.; Mohand-Said, S.; Leveillard, T.; Sahel, J. Invest. Ophthalmol Visual Sci. 2003, 44, 818-825.

(63) Lavalle, P.; Picart, C.; Mutterer, J.; Gergely, C.; Reiss, H.; Voegel, J.-C.; Senger, B.; Schaaf, P. J. Phys. Chem. B 2004, 108, 636-648.

(64) Tryoen-Toth, P.; Vautier, D.; Haikel, Y.; Voegel, J.-C.; Schaaf, P.; Chluba, J.; Ogier, J. J. Biomed. Mater. Res. 2002, 60, 657-667.

(65) Vautier, D.; Karsten, V.; Egles, C.; Chluba, J.; Schaaf, P.; Voegel, J.-C.; Ogier, J. J. Biomater. Sci., Polym. Ed. 2002, 13, 713-732.

(66) Salloum, D. S.; Olenych, S. G.; Keller, T. C. S.; Schlenoff, J. B. Biomacromolecules 2005, 6, 161-167.

(67) Taipale, J.; Keski-Oja, J. FASEB J. 1997, 11, 51-59.

(68) Brodkin, K. R.; Garcia, A. J.; Levenston, M. E. Biomaterials 2004, 25, 5929-5938.

(69) Gaur, V. P.; Liu, Y.; Turner, J. E. Exp. Eye Res. 1992, 54, 645659.

(70) Cao, W.; Wen, R.; Li, F.; Cheng, T.; Steinberg, R. H. Invest Ophthalmol. Visual Sci. 1997, 38, 1358-1366.

(71) Sheedlo, H. J.; Nelson, T. H.; Lin, N.; Rogers, T. A.; Roque, R. S.; Turner, J. E. Brain Res. Dev. Brain Res. 1998, 107, 57-69.

(72) Li, A.; Lane, W. S.; Johnson, L. V.; Chader, G. J.; Tombran-Tink, J. J. Neurosci. 1995, 15, 385-393.

(73) Ma, Z.; Gao, C.; Gong, Y.; Shen, J. Biomaterials 2005, 26, 12531259

(74) Hollyfield, J. G.; Rayborn, M. E.; Landers, R. A.; Myers, K. M. Exp. Eye Res. 1990, 51, 107-110.

(75) Kinkl, N.; Hageman, G. S.; Sahel, J. A.; Hicks, D. Mol. Vision 2002 $8,149-160$.

(76) Lavalle, P.; Boulmedais, F.; Ball, V.; Mutterer, J.; Schaaf, P.; Voegel, J.-C. J. Membr. Sci. 2005, 253, 49-56.

BM0505134 